\title{
Hasil Belajar Siswa MAN 2 Medan Pada Materi Faktor Kemunduran Dinasti Abbasiyah (1000-1258M) dengan Strategi Cooperative Learning Type Student Teams Achievement Divisions (STAD)
}

\author{
Nunzairina, Eko Haris Alamsyah
}

\begin{abstract}
Abstrac
This study aims to determine (1) Implementation of learning of Islamic History by subject decline of Abbasid dynasty through Strategy Learning Type Student Teams Achievement Divisions (STAD). (2) Increased student learning outcomes MAN 2 Medan through the implementation of Cooperative Learning Strategy Type Student Teams Achievement Divisions (STAD). This study is a classroom action research (PTK) using 2 learning cycles. The research method aims to improve the quality of classroom learning practice. The main purpose of PTK is to solve real problems that occur in the classroom as well as seeking a scientific answer why it can be solved through the action to be taken. The research findings are: (1) Implementation of learning by using Cooperative Learning Type Student Teams Achievement Divisions (STAD) strategy is appropriate learning. (2) Increasing the average score since the preliminary test before the action is 71,5 with the completeness of $22 \%$, the average value in cycle $\mathrm{I}$ is 77,4 with the completeness level $48 \%$, the average value in cycle II is 86,6 with $100 \%$ completeness level, thus the learning outcomes of students from cycle I to cycle II has increased.
\end{abstract}

Key Word: STAD, Hasil Belajar Siswa, Materi Kemunduran Abbasiyah

\begin{abstract}
Abstrak
Penelitian ini bertujuan untuk mengetahui (1) Pelaksanaan pembelajaran Sejarah Islam materi Kemunduran Dinasti Abbasiyah melalui Strategi Cooperative Learning Type Student Teams Achievement Divisions (STAD). (2) Peningkatan hasil belajar siswa MAN 2 Medan melalui penerapan Strategi Cooperative Learning Type Student Teams Achievement Divisions (STAD). Penelitian ini merupakan penelitian tindakan kelas dengan menggunakan 2 siklus pembelajaran. Metode penelitian bertujuan memperbaiki mutu praktik pembelajaran dikelas. Tujuan utama PTK adalah untuk memecahkan permasalahan nyata yang terjadi di dalam kelas sekaligus mencari jawaban ilmiah mengapa hal tersebut dapat dipecahkan melalui tindakan yang akan dilakukan.Temuan penelitian yaitu : (1) Pelaksanaan pembelajaran dengan menggunakan strategi Cooperative Learning Type Student Teams Achievement Divisions (STAD) sudah sesuai prosedur pembelajaran. (2) Meningkatnya nilai rata-rata sejak tes awal sebelum tindakan sebesar 71,5 dengan ketuntasan 22\%, Nilai rata-rata pada siklus I sebesar 77,4 dengan tingkat ketuntasan $48 \%$, nilai rata-rata pada siklus II sebesar 86, 6 dengan tingkat ketuntasan $100 \%$, dengan demikian hasil belajar siswa dari siklus I sampai siklus II mengalami peningkatan.
\end{abstract}


Kata Kunci : STAD, Hasil Belajar Siswa, Materi Kemunduran Abbasiyah

\section{PENDAHULUAN}

Sejarah Peradaban Islam merupakan rangkaian peristiwa kehidupan yang kaya dan menginspirasi manusia modern saat ini. Sejarah umat Islam sudah berjalan selama berabad-abad, Sejarah juga mencatat bahwa Islam pernah mengalami fase keemasan dalam alur perjalanan peradabannya yang dikenal dengan the golden age pada masa Dinasti Abbasiyah $(750 \mathrm{M}-1258 \mathrm{M})$. Perkembangan ilmu pengetahuan pada masa Dinasti Abbasiyah ini sangat gemilang dengan lahirnya para tokoh ilmuwan muslim seperti; al-Khawarizmi (780 M - $850 \mathrm{M})$ : bidang Matematika, Astronomi dan Geografi, Al-Farabi (820 $\mathrm{M}-950 \mathrm{M}$ ) bidang Filsafat dan masih banyak lagi tokoh-tokoh muslim lainnya pada masa kegemilangan tersebut, sehingga begitu kehancurannya seakan membenamkan umat Islam ini dari kesuksesan yang pernah terwarisi.

Kisah sejarah Dinasti Abbasiyah ini sangat menarik dikaji melihat perkembangan dinamika kehidupan intelektualnya. Oleh karena itu, perlu kiranya bagi generasi muda Islam untuk mengambil ibrah dari kisah sejarah tersebut, baik dari segi pencapaian dan kejayaan maupun faktor kemunduran atas runtuhnya dinasti yang sempat jaya tersebut.

Pada tulisan ini, penulis secara khusus meneliti tentang faktor mendasar yang menyebabkan runtuhnya dinasti Abbasiyah tersebut, karena faktor kemunduran ini dapat menjadi pembelajaran bagi umat Islam khususnya generasi muda masa kini untuk lebih meningkatkan kualitas diri dalam menghadapi tantangan global.

Terlebih lagi saat melakukan observasi mengenai pemahaman siswa terhadap mata pelajaran SKI materi faktor kemunduran Dinasti Abbasiyah masih banyak siswa yang belum memahami materi dengan baik, indikatornya adalah banyak nilai siswa yang tidak memenuhi KKM yaitu 75 (tujuh puluh lima) sebagai ketetapan di madrasah. Selain itu juga dengan adanya bincang-bincang dengan siswa tentang pembelajaran SKI disebutkan bahwa minat untuk pembelajaran SKI kurang semangat karena guru jarang menggunakan strategi atau metode pembelajaran yang menarik minat siswa.

Situasi ini menunjukkan perlunya seorang pendidik mencari solusi tepat untuk mengatasi kesulitan-kesulitan yang dialami siswa dalam memahami materi faktor penyebab runtuhnya dinasti Abbasiyah. Materi ini penting karena dapat mengambil ibrah dari peristiwa-peristiwa sejarah tersebut untuk masa depan negara yang kokoh.

Keberhasilan proses pembelajaran dalam suatu sekolah sangat dipengaruhi oleh kompetensi guru sebagai pendidik profesional. Peraturan pemerintah nomor 74 tahun 2008 tentang guru disebutkan bahwa guru adalah pendidik profesional dengan tugas utama mendidik, mengajar, membimbing, mengarahkan, melatih, 
menilai, dan mengevaluasi peserta didik pada pendidikan anak usia dini jalur pendidikan formal, pendidikan dasar dan pendidikan menengah. ${ }^{1}$

Ada beberapa cara untuk memenuhi hasil belajar agar sesuai dengan Kriteria Ketuntasan Minimal (KKM), salah satunya adalah menggunakan strategi yang efektif. Strategi yang menarik dan efektif adalah strategi yang sesuai dengan prinsip-prinsip penggunaan strategi dan mampu menarik minat siswa dalam memahami materi pelajaran yang disampaikan. Menurut Wina Sanjaya prinsip umum penggunaan strategi pembelajaran adalah tidak semua strategi pembelajaran cocok digunakan untuk mencapai semua tujuan dan semua keadaan. $^{2}$

Memperhatikan dan menimbang bahwa pembelajaran Sejarah Kebudayaan Isalam (SKI) sangat berguna untuk siswa dalam memahami peristiwa masa lalu terutama terkait aktivitas manusia pada kondisi keemasan maupun kemunduran umat Islam, sebagai bukti catatan sejarah. Berdasarkan ini peneliti melakukan observasi berkaitan tentang hasil belajar siswa pada mata pelajaran SKI materi Faktor Kemunduran Islam masa Abbasiyah di Kelas XI IPB MAN 2 Model Medan.

Salah satu strategi efektif ditawarkan dalam pembelajaran SKI adalah strategi pembelajaran koperatif tipe Student Teams-Achievement Divisions $(S T A D)$. Strategi ini sangat tepat digunakan karena mata pelajaran SKI materi faktor kemunduran Dinasti Abbasiyah melibatkan siswa berdiskusi antar sesamanya dengan memikirkan secara langsung apa yang terjadi pada faktor kemunduran Dinasti Abbasiyah berdasarkan sumber-sumber yang ditemukan dan dampaknya bagi kehidupan umat Islam masa kini. Strategi ini dilaksanakan melalui sharing proses antara peserta didik, sehingga dapat mewujudkan pemahaman bersama antara peserta didik itu sendiri. Pembagian tema-tema berdasarakan materi tersebut dibagi dalam kelompok untuk mengidentifikasi kajiannya sehingga diharapkan pemahaman siswa dapat membaik dengan nilai melebihi KKM.

Pengidentifikasian masalah tersebut memunculkan pertanyaan; Bagaimana hasil belajar siswa pada materi faktor kemunduran Dinasti Abbasiyah sebelum maupun sesudah diterapkannya strategi Student Teams-Achievement Divisions (STAD), dan apakah terjadi peningkatan setelah strategi STAD dijalankan dengan beberapa kali pembelajaran. Hal inilah yang akan diselesaikan dalam tulisan ini.

\section{HASIL PEMBAHASAN}

\section{Ruang Lingkup Materi Faktor Kemunduran Dinasti Abbasiyah}

Penyebab mundurnya Dinasti Abbasiyah apabila diidentifikasi memiliki banyak faktor yang tidak bisa dipungkiri baik secara internal maupun eksternal.

${ }^{1}$ Imam Wahyudi. 2012. Pengembangan Pendidikan: Strategi Inovatif dan Kreatif dalam mengelola Pendidikan Secara Komprehensif, Jakarta: Prestasi Pustakarya, h. 28.

${ }^{2}$ Wina Sanjaya. 2011. Strategi Pembelajaran Berorientasi Standar Proses Pendidikan, cet.8, Jakarta: Kencana. h. 131. 
Masa kemunduran dimulai sejak Abbasiyah diperintah oleh khalifah Abu Ja'far Muhammad al Muntashir (247 - 248 H / 861 - 862 M) sampai jatuhnya Baghdad saat khalifah berada di tangan Abu Ahmad Abdullah al Mu'tashim (640 - 656 H / $1242-1258 \mathrm{M})^{3}$

Kemunduran sebuah imperium pasti karena adanya faktor-faktor yang menyebabkan terjadinya ketidakseimbangan dinasti tersebut dalam menjalankan pemerintahannya, ketidakseimbangan itu salah satunya bisa diletakkan pada pola kepemimpinannya dan bisa juga yang lainnya. Sejarah kekuasaan Dinasti Abbasiyah terlihat bahwa apabila pemimpinnya/khalifah kuat, maka para menteri cenderung kuat sebagai tonggak kepala pegawai sipil, tetapi jika pemimpinnya/khalifah lemah maka para menteri akan berkuasa mengatur roda pemerintahannya. Sehingga kepemimpinan yang demikian menjadi faktor-faktor yang bisa dikaitkan dalam melacak kemunduran dinasti tersebut. Kelemahan khalifah pada Dinasti Abbasiyah memiliki faktor yang sangat luas ketika diidentifikasi penyebab-penyebab kemundurannya bahkan penyebabnya bisa saling berkaitan. Pada tulisan ini materi faktor kemunduran Dinasti Abbasiyah memunculkan 4 (empat) faktor yang dibahas dalam proses pembelajaran yang diberlakukan pada siswa MAN 2 Model Medan dengan strategi STAD. Keempat faktor itu adalah; Persaingan Antar Bangsa, Kemerosotan Ekonomi, Konflik Keagamaan, Adanya friksi di dalam tubuh Dinasti Abbasiyah. Faktor-faktor ini dikembangkan dalam proses pembelajaran untuk dipahami siswa sebagai pembelajaran di kelas.

\section{Langkah-langkah strategi Student Teams-Achievement Divisions (STAD) dalam Pembelajaran Sejarah Islam}

Strategi pembelajaran merupakan suatu rencana, cara pandang dan pola pikir guru dalam mengorganisasikan isi pelajaran, penyampaian pelajaran, dan pengelolaan kegiatan belajar mengajar untuk mencapai tujuan pendidikan. Dalam strategi pembelajaran, terkandung makna perencanaan. Artinya strategi pada dasarnya masih bersifat konseptual tentang keputusan-keputusan yang akan diambil dalam suatu pelaksanaan pembelajaran. ${ }^{4}$ Strategi pembelajaran koperatif merupakan salah satu solusi dari permasalahan yang di alami peserta didik baik itu masalah ketuntasan nilai maupun perilaku peserta didik ketika proses belajar mengajar berlangsung di sekolah. Perilaku buruk peserta didik dan nilai peserta didik yang tidak mencapai ketuntasan (KKM) dapat disebabkan oleh strategi pembelajaran yang tidak efektif yang dipraktikkan pendidik. Oleh karenanya, peneliti berasumsi bahwa strategi pembelajaran yang efektif dapat menunjang kesuksesan proses belajar mengajar terutama pada karakteristik pembelajaran Sejarah yang mengandalkan kognitif dan monoton. Proses pembelajaran sejarah perlu memiliki inovasi-inovasi dalam pengembangan pembelajarannya. Oleh karena itu penulis menawarkan strategi STAD untuk melihat proses pembelajaran sejarah dapat berlangsung.

\footnotetext{
${ }^{3}$ Wahyu Ilaihi dan Harjani Hefni.Pengantar, h. 119.

${ }^{4}$ Khaniful. 2013. Pembelajaran Inovatif. Yogyakarta : Ar-Ruzz Media, h.15.
} 
Pembelajaran kooperatif (cooperative learning) dengan STAD merupakan bentuk pembelajaran dengan cara siswa belajar dan bekerja dalam kelompokkelompok kecil secara kolaboratif, yang anggotanya terdiri dari 4 sampai dengan 6 orang, dengan struktur kelompok yang bersifat heterogen. ${ }^{5}$ Strategi Cooperative Learning Type Student Teams Achievement Divisions (STAD), penulis menyampaikan bahwa strategi STAD sangat relevan untuk mensukseskan proses pembelajaran. Oleh karena itu pembelajaran SKI yang banyak menggunakan konsep-konsep sangat memungkinkan untuk pelaksanaan diskusi dalam teamteam yang mampu menuntaskan materi-materi sejarah secara mendalam. pada materi Faktor kemunduran Dinasti Abbasiyah.

Adapun langkah-langkah strategi STAD dalam pembelajaran Sejarah untuk materi Faktor Kemunduran Dinasti Abbasiyah adalah sebagai berikut :

a. Menyampaikan tujuan dan motivasi dari pembelajaran

Menyampaikan tujuan pelajaran yang ingin dicapai pada pembelajaran tersebut dan memotivasi siswa untuk belajar.

b. Melakukan pembagian kelompok

Siswa dibagi kedalam 4 (empat) kelompok dimana setiap kelompoknya terdiri dari 4-5 siswa yang memprioritaskan heterogenitas (keragaman) kelas dalam prestasi akademik, gender/jenis kelamin, ras atau etnik.

c. Presentasi dari guru tentang materi sejarah

Guru menyampaikan materi pelajaran dan pentingnya pokok bahasan tersebut dipelajari. Guru memberi motivasi siswa agar dapat belajar dengan aktif dan kreatif. Di dalam proses pembelajaran guru dibantu oleh media, demonstrasi, pertanyaan atau masalah nyata yang terjadi dalam kehidupan sehari-hari. Dijelaskan juga tentang keterampilan dan kemampuan yang diharapkan dikuasai siswa, tugas dan pekerjaan yang harus dilakukan serta cara-cara mengerjakannya. Dengan membagi subsub materi yang dibahas dalam masing-masing kelompok.

d. Kegiatan belajar dalam tim (Kerja Tim)

Siswa belajar dalam kelompok yang telah dibentuk. Guru menyiapkan lembaran kerja sebagai pedoman untuk kerja di dalam tim, sehingga semua anggota menguasai dan masing-masing memberikan kontribusi. Selama tim bekerja, guru melakukan pengamatan, memberikan bimbingan, dorongan dan bantuan bila diperlukan. Kerja tim ini merupakan ciri terpenting dari STAD.

e. Kuis (Evaluasi)

Guru mengevaluasi hasil belajar melalui pemberian kuis tentang materi yang dipelajari dan juga melakukan penilaian terhadap hasil presentasi hasil kerja masing-masing kelompok. Siswa diberikan kursi secara individual dan tidak dibenarkan bekerjasama. Ini dilakukan untuk menjamin agar siswa secara individu bertanggung jawab kepada diri sendiri dalam memahami bahan ajar tersebut. Guru menetapkan skor batas

${ }^{5}$ Abdul Majid. Strategi, h. 174. 
penguasaan untuk setiap soal, misalnya $60,75,84$ dan seterusnya sesuai dengan tingkat kesulitan siswa. ${ }^{6}$

Aktivitas strategi ini mendorong siswa untuk terbiasa bekerja sama dan saling membantu dalam menyelesaikan suatu masalah, tetapi pada akhirnya bertanggung jawab secara mandiri, sehingga mau tidak mau para siswa dalam tim berusaha mencari tahu pembahasan materi yang diembankan pada timnya.

\section{Hasil Belajar Siswa pada Materi Faktor Kemunduran Dinasti Abbasiyah melalui strategi Student Teams-Achievement Divisions (STAD)}

Mata pelajaran Sejarah merupakan salah satu mata pelajaran yang membahas peristiwa peristiwa yang mempengaruhi perjalanan peradaban dan kebudayaan Islam. Individu yang memahami sejarah akan mampu bertindak dengan cermat dan berfikir jangka panjang untuk mengambil pelajaran dari peristiwa sejarah yang telah dialami. Jika sejarah dimasa lalu merupakan tinta emas kebaikan maka akan berusaha menorehkan kembali tinta emas tersebut, namun jika sejarah itu adalah sejarah kelam maka akan menjadi pembelajaran agar sejarah kelam tersebut tidak dialami lagi oleh umat Islam. Catatan sejarah dinasti Abbasiyah merupakan salah satu peradaban emas Islam yang mewarnai dan memperkaya perjalanan umat Islam.Oleh karena itu, banyak hal yang dapat diambil dari sejarah Abbasiyah tersebut. Strategi Cooperative Learning Type Student Teams Achievement Divisions (STAD) merupakan salah satu strategi yang mementingkan kebersamaan dan diskusi dalam menyelesaikan pembelajaran sejarah. Strategi ini menekankan sifat sosial dan kerjasama dalam kelompok yang berbeda-beda kemampuan dan latar belakang. Strategi ini menekankan sifat sosial pembelajaran dan memandang bahwa perilaku kooperatif dapat merangsang siswa baik secara sosial maupun intelektual. Strategi ini terbukti ampuh dalam meningkatkan hasil belajar siswa pada mata pelajaran Sejarah materi faktor kemunduran Dinasti Abbasiyah, sebagaimana temuan dalam penelitian yang dilakukan melalui dua siklus. Hasil temuannya bahwa secara komprehensif menunjukkan terjadi peningkatan hasil belajar siswa dengan menggunakan strategi STAD. Peneliti terlibat langsung dalam penelitian ini sehingga keakuratan data dalam penelitian ini dapat dipertangggung jawabkan.

Hasil penelitian dengan pra tindakan dilakukan terhadap subyeknya yaitu siswa kelas XI IPB MAN 2 Model Medan yang berjumlah 27 orang. Proses pembelajaran berjalan dengan apa adanya tanpa melibatkan adanya stategi pembelajaran. Pada jam pertama pertemuan suasana kelas tidak mendukung dengan terlihatnya kebosanan dan kejenuhan para siswa karena proses pembelajaran yang terjadi hanya satu arah. Hasil pengamatan pembelajaran pra tindakan ini juga menunjukkan hasil pretes siswa hanya 6 orang dari 27 siswa yang tuntas dalam memenuhi KKM.

Pelaksanaan siklus dalam proses pembelajaranpun dilakukan dengan menunjukkan bahwa masih banyak siswa yang merasa strategi pembelajaran yang

${ }^{6}$ Rusman.Model, h. 215-216. 
dilakukan selama ini kurang variatif karena hasil informasi dari siswa belum dikenalnya strategi STAD ini dalam proses pembelajarannya. Dengan demikian perlulah memberlakukan pembelajaran dengan strategi STAD model PTK yang menggunakan siklus.

Pelaksanaan pada siklus pertama menunjukkan bahwa proses pembelajaran sudah menggunakan tindakan yang menggunakan strategi STAD. Namun karena strategi ini belum dikenal maka para siswa merasa masih bingung dan kaku pada saat mengikuti pembelajaran sejarah. Pada pengamatan peneliti menemukan telah terjadi perubahan perilaku belajar siswa meski tidak signifikan. Siswa dalam hal ini mulai merasa senang melaksanakan aktivitas pembelajaran, sehingga mayoritas siswa termotivasi dan kembali bersemangat untuk memahami lebih lanjut materi ajar yang disampaikan, terlihat dengan tugas-tugas yang diberikan dapat diselesaikan yang tepat. Walaupun masih ada sebagian siswa lain merasa kebingungan terhadap materi ajar yang disampaikan sehingga kurang bersemangat, kurang merespon dan kurang menyimak materi ajar dengan seksama, karena pada siklus 1 masih proses pembelajaran awal dengan menggunakan STAD tersebut.

Selama dilakukan pengamatan pada siklus I, ditemukan bahwa siswa melaksanakan beberapa hal sebagai berikut : siswa memperhatikan penjelasan guru, mengerjakan tugas yang diberikan, mampu menjawab pertanyaan yang diajukan guru dan aktif dalam pembelajaran sesuai dengan strategi yang diterapkan dan siswa belum mampu melaksanakan beberapa kegiatan seperti berani bertanya, terdapat siswa yang kurang memahami materi pelajaran dan terdapat siswa yang bermain saat proses pembelajaran berlangsung.

Kemudian selama dilakukan pengamatan pada siklus II, ditemukan aktivitas yang mampu dilaksanakan siswa seperti memperhatikan penjelasan guru dengan seksama, mampu menjawab pertanyaan, dapat memahami materi pelajaran faktor kemunduran dinasti Abbasiyah dengan baik, aktif dalam pembelajaran sesuai strategi yang diterapkan, tidak bermain-main saat proses pembelajaran dan mengerjakan tugas dengan baik. Hanya ada satu indikator pengamatan yang belum diaksanakan siswa dengan baik yaitu siswa belum berani bertanya kepada guru. Secara umum dapat diketahui bahwa berdarkan tes yang dilakukan sterjadi peningkatan dalam perilaku siswa pada pembelajaran sejarah dengan diterapkannya strategi STAD. Hasil pelaksanaan tes siklus II menunjukkan bahwa hasil belajar siswa kelas XI IPB MAN 2 Model Medan yang berjumlah 27 orang dengan dua kali proses pembelajaran pada materi faktor kemunduran dinasti Abbasiyah mencapai rata-rata 86, $6 \%$ dengan kategori tinggi. Sedangkan persentase keberhasilan siswa secara klasikal berjumlah $100 \%$.

Sementara itu, apabila dicermati kinerja guru pada siklus I sebesar $80,77 \%$, dan kinerja guru pada siklus II sebesar 92,31\%. Hal ini menunjukkan meningkatnya kualitas guru dalam mendidik siswa di kelas XI IPB MAN 2 Model Medan.Hal ini membuktikan bahwa kualitas guru berbanding lurus kepada meningkatnya hasil belajar siswa dari siklus I ke siklus II.

Dengan demikian melalui data-data tersebut peneliti beranggapan bahwa Strategi Cooperative Learning Type Student Teams Achievement Divisions (STAD) merupakan salah satu solusi untuk meningkatkan hasil belajar siswa 
karena dari penelitian yang dilakukan di kelas XI IPB MAN 2 Model Medan terdapat peningkatan keseriusan belajar siswa yang berimplikasi terhadap meningkatnya hasil belajar siswa dari pre test, siklus I sampai kepada siklus II.

Hasil pengamatan yang peneliti lakukan terhadap siswa kelas XI IPB MAN 2 Model Medan yang berjumlah 27 orang siswa menunjukkan bahwa adanya peningkatan pemahaman dan penguasaan siswa terhadap mata pelajaran Sejarah materi faktor kemunduran Dinasti Abbasiyah. Peningkatan pada siklus II sudah signifikan jika dibandingkan pada siklus I, hal ini menunjukkan pelaksanaan pembelajaran dengan menggunakan STAD sudah berjalan sesuai dengan yang diharapkan peneliti.

Selanjutnya dari hasil pelaksanaan tes siklus II menunjukkan bahwa hasil belajar siswa kelas XI MAN 2 Model Medan yang berjumlah 27 orang pada mata pelajaran sejarah materi faktor kemunduran Dinasti Abbasiyah mencapai rata-rata 86, $6 \%$ dengan kategori tinggi. Sedangkan persentase keberhasilan siswa secara klasikal berjumlah $100 \%$. Dimana seluruh siswa dikelas tersebut yang berjumlah 27 orang mencapai hasil belajar yang ditetapkan. Hasil ini menunjukkan kriteria keberhasilan yang telah ditentukan sebelumnya sebesar $80 \%$ sudah tercapai.

Dengan demikian, peneliti berasumsi bahwa pembelajaran dengan menerapkan strategi Cooperative Learning Type Student Teams Achievement Divisions (STAD) sudah berjalan sukses dengan memenuhi kriteria ketuntasan minimal yang diharapkan.

Selanjutnya jika diperhatikan kinerja guru pada siklus kedua juga telah mengalami peningkatan yang baik sehingga mengindikasikan bahwa guru sungguh-sungguh dalam mentransfer ilmu dengan menerapkan strategi pembelajaran.

Dengan berpatokan terhadap data-data yang peneliti dapatkan di lapangan, maka peneliti memutuskan untuk tidak lagi melakukan pelaksanaan pada siklus berikutnya, karena apa yang menjadi target peneliti dalam penelitian ini telah tercapai dengan baik yaitu adanya peningkatan hasil belajar siswa pada mata pelajaran SKI materi faktor kemunduran Dinasti Abbasiyah dengan menggunakan strategi Cooperative Learning Type Student Teams Achievement Divisions (STAD).

Selanjutnya dibawah ini akan diuraikan tentang rekapitulasi hasil belajar siswa pada saat pre test, siklus I dan siklus II.

\section{Tabel 4.11}

Ketuntasan Belajar Siswa Secara Klasikal Pada Pre Test, Siklus I dan Siklus II

\begin{tabular}{|l|l|l|l|}
\hline No. & $\begin{array}{l}\text { Deskripsi Tingkat Penguasaan } \\
\text { Siswa }\end{array}$ & Nilai rata-rata & Jumlah Siswa \\
\hline 1. & Pre Test & $22 \%$ & 27 \\
\hline 2. & Siklus I & $48 \%$ & 27 \\
\hline 3. & Siklus II & $100 \%$ & 27 \\
\hline
\end{tabular}

Berdasarkan tabel diatas dapat diketahui secara klasikal bahwa hasil belajar siswa pada hasil pre test $22 \%$, siklus I $48 \%$ dan siklus II $100 \%$. Dengan demikian dapat diambil kesimpulan bahwa hasil belajar siswa mengalami 
peningkatan. Berdasarkan data tersebut dapat diketahui bahwa proses pembelajaran SKI materi faktor kemunduran Dinasti Abbasiyah dengan menggunakan strategi Cooperative Learning Type Student Teams Achievement Divisions (STAD) dapat meningkatkan hasil belajar siswa.

\section{PENUTUP}

Proses penelitian yang dilakukan peneliti membawa pada sebuah kesimpulan bahwa strategi Cooperative Learning Type Student Teams Achievement Divisions (STAD) sangat relevan untuk dilakukan karena dapat meningkatkan hasil belajar siswa pada mata pelajaran SKI materi faktor kemunduran dinasti Abbasiyah di kelas XI IPB MAN 2 Model Medan.

Proses awal yang dilalui dengan pra tindakan, siklus I dan siklus II menunjukkan meningkatnya hasil belajar siswa diindikasikan dengan berhasil memenuhi kriteria keberhasilan yang ditetapkan guru dan peneliti yaitu sebesar 80 $\%$. Pada pre test nilai rata-rata yang didapat adalah $22 \%$, pada siklus I $48 \%$ dan siklus II $100 \%$. Hal tersebut mengindikasikan bahwa terjadi peningkatan secara signifikan pada peserta didik. Sehingga strategi ini sangat baik untuk diaplikasikan pada mata pelajaran lain yang memiliki konsep yang sama seperti mata pelajaran SKI.

Kemudian, setelah dilakukan pengamatan terhadap kinerja guru pada siklus I diperoleh penilaian sebesar $80,77 \%$, dan kinerja guru pada siklus II sebesar 92,31\%. Hal ini menunjukkan meningkatnya kualitas guru dalam mendidik siswa di kelas XI IPB MAN 2 Model Medan. Hal ini membuktikan bahwa kualitas guru berbanding lurus kepada meningkatnya hasil belajar siswa dari siklus I ke siklus II. Sehingga strategi tersebut sangat relevan untuk digunakan untuk memperbaiki hasil belajar siswa. 


\section{Daftar Pustaka}

Agung, Iskandar, Panduan Penelitian Tindakan Kelas Bagi Guru. Jakarta: Bestari Buana Murni, 2012.

Arikunto, Suharsimi, Dasar-Dasar Evaluasi Pendidikan. Jakarta: Bumi Aksara, 2009.

Asari, Hasan, Menguak Sejarah Mencari Ibrah. Bandung: Cita pustaka Media, 2006.

Ibnu Badar Al Tabany, Trianto, Mendesain Model Pembelajaran Inovatif, Progresif, dan Kontekstual. Jakarta: Kencana, 2014.

Ilaihi, Wahyu dan Harjani Hefni.Pengantar Sejarah Dakwah. Jakarta: Kencana, 2007.

Khaniful, Pembelajaran Inovatif. Yogyakarta: Ar-Ruzz Media, 2013.

L. Silbermen, Melvin, Active Learning; 101 Strategi Pembelajaran Aktif. Terj.Raisul Muttaqien. Bandung: Nuansa Cendekia, cet-X, 2014.

Majid, Abdul, Strategi Pembelajaran. Jakarta: Remaja Rosdakarya, 2014.

Mardianto, Psikologi Pendidikan. Medan: Perdana Publishing, cet- V, 2014.

Rusman, Model-Model Pembelajaran. Jakarta: RajagrafindoPersada, cet-VI, 2013.

Salim dan Syahrum, Metode Penelitian Kualitatif. Bandung: CiptaPustaka Media, 2010.

Sanjaya, Wina, Strategi Pembelajaran Berorientasi Standar Proses Pendidikan, Jakarta: Kencana, cet-VIII, 2011.

Sudaryono, Dasar-Dasar Proses Pembelajaran. Yogyakarta: Grahallmu, 2012.

Sudijono, Anas, Pengantar Evaluasi Pendidikan. Jakarta: RajagrafindoPersada, 2009.

Syah, Muhibbin. Psikologi Pendidikan dengan Pendekatan Baru, Ed. Revisi. Bandung: Remaja Rosdakarya, 2007.

Trianto. Model Pembelajaran Terpadu dalam Teori dan Praktik. Jakarta: Prestasi Pustaka, 2007.

Warsono dan Hariyanto. Pembelajaran Aktif. Bandung: Remaja Rosdakarya. CetIII, 2014.

Yatim, Badri. Sejarah Peradaban Islam. Jakarta: Rajagrafindo Persada. Cet-XV, 2013. 